\title{
Equal Pay, Comparable Work, and Job Evaluation
}

The requirement of equal pay for equal work under Title VII of the Civil Rights Act of $1964^{1}$ and the Equal Pay Act of $1963^{2}$ has not eliminated sex-based discrimination in compensation. Nearly half of all women workers hold traditionally female, substantially sex-segregated jobs. ${ }^{3}$ As a result of widespread discrimination by employers, ${ }^{*}$ these workers receive lower wages than workers in predominantly male and integrated jobs. The courts have generally refused to order higher wages for many women in sex-segregated jobs on the ground that the work required of them is not equal ${ }^{5}$ to better paid work performed by men. ${ }^{6}$

To achieve the congressional objective of eradicating unfair employment practices, Title VII must be expanded beyond the equal

1. 42 U.S.C. $\$ \$ 2000$ e to 2000 e-17 (1976 \& Supp. III 1979).

2. 29 U.S.C. $\$ 206$ (d) (1976). The Equal Pay Act is an amendment to the Fair Labor Standards Act, 29 U.S.C. $\$ \$ 201.219$ (1976 \& Supp. III 1979).

3. See Barrett, Women in the Job Market: Occupations, Earnings, and Career Opportunitics, in The Subtle Revolution 31, 47 (R. Smith ed. 1979) (almost half of all women workers are employed in jobs that are at least $75 \%$ female); cf. Reagan, De Facto Job Segregation, in WOMEN IN THE U.S. LABor Force 90, 94-95 (A. Cahn ed. 1979) (concentration of women workers in " 'female' jobs" has been increasing since 1960); U.S. Comm'N on Civil Rights, Social Indicators of Equality for Minorities and Women 39, $42-44$ (1978) (for majority-group men and women to have identical occupational distributions, approximately $66 \%$ of female workers in 441 occupational categories would have to change jobs).

4. See pp. 660-64 infra (describing discriminatory treatment leading to low wages for women in sex-segregated occupations).

5. Jobs are equal for the purposes of the Equal Pay Act if they have substantially the same content. See, e.g., Corning Glass Works v. Brennan, 417 U.S. 188, 203 n.24 (1974) (women's day-shift inspection work equal to men's night shift inspection work because duties assigned exclusively to men-cleaning, lifting, and packing-were of "little consequence"); Shultz $\mathrm{v}$. Wheaton Glass Co., 421 F.2d 259, 264 (3d Cir.), cert. denied, 398 U.S. 905 (1970) (female selector-packers' work equal to male selector-packers' work because not all men performed additional physical labor, and because snap-up boys routinely performed physical labor for lower wage than women's). Jobs that do not meet the legal test of equality may nevertheless be comparable in the sense that they are equally difficult or important. See Christensen v. Iowa, 563 F.2d 353, 354 (8th Cir. 1977) (clerical and physical plant jobs found to be comparable based on employer's job evaluation). See generally R. SIBson, CoMpensation 37 (1974) (explaining concept of job worth).

b. See, e.g., Lemons v. City \& County of Denver, 620 F.2d 228, 229-30 (10th Cir.), cert. denied, 101 S. Ct. 244 (1980) (nurses' jobs not equal to jobs in general administrative classification); Christensen v. Iowa, 563 F.2d 353, 356-57 (8th Cir. 1977) (clerical work not equal to physical plant work). But see International Union of Electrical, Radio \& Mach. Workers v. Westinghouse Elec. Corp., 631 F.2d 1094, 1096-97 (3d Cir.), petition for cert. filed, 49 U.S.L.W. 3410 (U.S. Nov. 14, 1980) (No. 80-781) (system setting low wages for all job categories filled predominantly by women violates Title VII regardless of whether such jobs are equal to better paid male jobs). 
pay for equal work standard. This Note argues that Title VII also requires equal pay for comparable work-work that is of equal value or importance to the employer. ${ }^{7}$ The Note then proposes a method for using job evaluation procedures to identify jobs held by women that are comparable to better paid jobs occupied by men. Because these procedures are widely used by employers to establish relative wages for jobs with different content, they are a promising answer to the problem of determining when jobs are comparable. ${ }^{\mathrm{s}}$

\section{Pay Discrimination in Sex-Segregated Jobs}

Private and public enforcement ${ }^{9}$ of the federal prohibitions against sex-based discrimination in compensation has not reduced the disparity between the earnings of male and female workers in the United States. During the past twenty-five years, women working full-time outside the home have earned, on average, sixty percent of men's full-time earnings. ${ }^{10}$ Part of this disparity is attributable to the payment to women in sex-segregated jobs of wages that are lower than the wages paid to men in different but comparable jobs. ${ }^{11}$ This type of pay discrimination is not currently remediable under federal law

7. See note 5 supra (defining comparable work).

8. See pp. 674-76 infra (describing job evaluation procedures).

9. Both Title VII and the Equal Pay Act can be enforced by either governmental agencies or private parties. Title VII authorizes the Equal Employment Opportunity Commission (EEOC) to investigate employment practices and, when appropriate, to initiate conciliation proceedings or file suit in federal district court. 42 U.S.C. $\$ 2000$ e-5(b), $-\check{\partial}(\mathrm{f})$ (1976). An individual who wishes to challenge discriminatory practices under Title VII must file her charge with the EEOC. $I d$. $\$ 2000 \mathrm{e}-5(\mathrm{~b})$. The charge must be filed with or referred to a state or local agency when (1) a state or local law proscribes the act alleged, and (2) a state or local entity has civil or criminal enforcement powers. The EEOC may assume jurisdiction if the state or local agency takes no action within sixty days. $I d$. $\S 2000 c-5(c),-5(d)$. If the EEOC determines that legal action is necessary or appropriate, it may commence enforcement proceedings. If the EEOC dismisses the complainant's charge or fails to commence an action within 180 days of its filing, the aggrieved individual may bring suit against her employer. Id. $\$ 2000 \mathrm{e}-5(\mathrm{f})$.

The Fair Labor Standards Act, 29 U.S.C. $\$ \$ 201-219$ (1976 \& Supp. III 1979), provides the enforcement mechanism for the Equal Pay Act. The EEOC may initiate litigation or, if the Commission does not file suit, an aggrieved employee may sue to enforce the Act. Id. \$ 216; see Exec. Order No. 12,106, 3 C.F.R. 263 (1979), reprinted in 42 U.S.C. $\$ 2000 e-4$ (Supp. III 1979) (transferring equal pay enforcement functions from Department of Labor to EEOC).

10. See C. Lloyd \& B. Niemi, The Economics of Sex Differentials 152 (1979) (in 1955, female workers' median earnings equaled $63.9 \%$ of male median earnings; in 1965, $60.0 \%$; in $1977,58.9 \%$ ); Barrett, supra note 3 , at 34 (showing relative earnings by occupation); cf. Keyserling, Women's Stake in Full Employment: Their Disadvantaged Role in the Economy-Challenges to Action, in WoMEN IN THE U.S. LABOR Force 25, 29 (A. Cahn ed. 1979) (measured by comparative carnings, women's relative position in labor force deteriorating).

11. See pp. 662-64 infra (describing wage determination when jobs are sex-segregated). 
because most courts have held that Title VII and the Equal Pay Act require that men and women receive equal wages only when they perform substantially equal work. ${ }^{12}$

\section{A. Discrimination in Wage Determination}

The disparity between the average earnings of male and female workers results in part from education and career choices made by women, and so would exist to some degree even in the absence of discrimination by employers. ${ }^{13}$ As a group, women in the labor force are less well educated ${ }^{14}$ and less likely to have acquired job-specific training than men. Most women who have received vocational education work in traditionally female occupations. ${ }^{15}$ Moreover, at present women are more likely than men to engage in nonmarket work ${ }^{16}$ during part of their adult lives. ${ }^{17}$ To the extent that their worklives are discontinuous, women forgo employment experiences that might enable them to command higher wages as their careers progress. ${ }^{18}$

12. See notes $45 \& 46$ infra (citing cases).

13. The term "discrimination" is used in two senses in this Note. First, as economists use the term, "discrimination" refers to decisions about the distribution of wages and jobs that are influenced by factors not related to the productivity of individual workers. Discrimination in this sense has two components. One is pay discrimination: wage differentials that do not reflect the actual productivity of individual workers. The other is occupational discrimination: patterns of occupational distribution that are determined by worker characteristics not related to productivity. See J. Madpen, The Economics of Sex Discrimin.tition 1.2 (1973) (discussing types of discrimination); R. Tsuchigane \& N. Dodge, Economic Discrimination Against Women in the United States 1-2 (1974) (same).

Second, "discrimination" denotes the set of behaviors that are proscribed by law. This Note argues that the payment of unequal wages to men and women performing comparable work is discrimination in the legal sense and therefore should be remediable under Title VII.

14. See C. Lloyd \& B. NIEMI, supra note 10, at 99-101 (women less likely to complete college than men); U.S. Comm'N oN CiviL RIGHTs, supra note 3 , at 12-15 (educational attainments of males exceed those of females at both high school and college levels for nearly all racial and ethnic groups studied).

15. See C. Lloyd \& B. Niem, supra note 10, at 104-07 (women pursue less vocationally oriented studies than men); Cahn, Summary, in WoMeN IN THE U.S. LABor Force 1, 18.19 (A. Cahn ed. 1979) (women's opportunities for rocational training or apprenticeship generally limited to traditionally female fields).

16. Nonmarket work is productive work in the household. See C. Lloyd \& B. NIEMI, sutpra note 10, at 22-29 (reviewing economic theory of the household).

17. A married woman's participation in the workforce is more likely to be discontinuous than a single woman's or a man's. See id. at 65 (marriage is primary correlate of different labor supply functions for men and women); $c f$. J. MAdDEN, supra note 13, at 9 (best predictors of woman's labor force participation are her marital status and number and age of her children). But see C. Lloyd \& B. NiemI, supra note 10, at 70-72, 74-76 (married women may no longer be as likely to leave work force to bear and raise children).

18. See J. Kreps, Sex in the Marketplace: American Women at Work 44-45 (1971) (threat of discontinuity or actual lack of job experience in woman's worklife is "greatest single barrier" to higher wages); Polachek, Discontinuous Labor Force Participation and 
These work-preparation and employment patterns may result in some degree of difference in productivity between men and women. Such sex-based productivity differences may, in turn, lead to pay differentials that, although arguably traceable to some form of discrimination against women, are not the direct result of discrimination by their current employers. ${ }^{19}$

Despite the importance of these legally neutral ${ }^{20}$ factors, discrimination against women by their employers is responsible for much of the difference between the wages paid to men and women. ${ }^{21}$ Moreover, although these factors help to explain the aggregate sex-based

Its Effect on Women's Market Earnings, in SEX, Discrimination, AND THE Division OF LABOR 90, 111 (C. Lloyd ed. 1975) (women with discontinuous employment history have lower earnings potential than workers generally). But see Corcoran, The Structure of Female Wages, AM. Econ. REv., May 1978, at 165, 170 (work experience, job tenure, and full or part time nature of past work influence wages more than intermittent character of previous participation in labor force); Keyserling, supra note 10, at 29 (disparity between earnings of men and women increasing although discontinuity in women's employment patterns decreasing).

19. Sex-based productivity differences may be related to the different socialization of males and females. See Boulding, Toward a Theory of Discrimination, in EQual EMploYMENT OPPORTUNITY AND THE AT\&T CASE 9, 13 (P. Wallace ed. 1976) (discrimination includes processes that make persons unfit for some societal roles); Taub, Keeping Women in their Place: Stereotyping Per Se as a Form of Employment Discrimination, 21 B.C. L. REv. 345, 350 (1980) (socialization and family and group pressures constrain women's training and job choices). Although such influences may be viewed as discrimination from a societal perspective, antidiscrimination law adopts an individualist perspective, focusing on the particular actions of identifiable discriminators rather than on the more impersonal forces of society. See, e.g., Freeman, Legitimizing Racial Discrimination Through Antidiscrimination Law: A Critical Review of Supreme Court Doctrine, 62 MiNN. L. REv. 1049, 1053-54 (1978) (law adopts "perpetrator perspective," viewing discrimination as wrongful conduct of particular actors); Powers, Sex Segregation and the Ambivalent Directions of Sex Discrimination Law, 1979 WIs. L. REv. 55, 89-91 (sex discrimination law adopts individualist approach, which emphasizes individual achievement, formal equality, and restricted purposes of law). In addition to socialization, accurate information about current discrimination by employers may influence women's decisions. See J. KREPS, supra note 18 , at 45 (women may realistically appraise lower rates of return from expenditures for training); Taub, supra, at $350 \mathrm{n} .21$ ("perceptual equilibrium" may exist in which employer attitudes and employee responses are mutually reinforcing). Finally, sex-based productivity differences may be related to discrimination in academic or vocational education. This type of discrimination is subject to legal attack. See, e.g., Education Amendments of 1972, $\$ 901,20$ U.S.C. $\$ 1681$ (1976) (Title IX) (prohibiting sex-based discrimination in institutions of vocational and higher education); Civil Rights Act of 1964, $\S 703(\mathrm{~d}), 42$ U.S.C. $\$ 2000 \mathrm{e}-2(\mathrm{~d})$ (1976) (Title VII) (prohibiting sex-based discrimination in apprenticeship and training programs); Cannon v. University of Chicago, 441 U.S. 677, 717 (1979) (finding implied private right of action under Title IX).

20. These factors are neutral with respect to determining employer liability for pay discrimination because dissimilar treatment based on job-related qualifications is not prohibited by Title VII. But cf. note 19 supra (discrimination in vocational and cducational training may be illegal).

21. See C. Lloyd \& B. Niemi, supra note 10 , at $237-38$ (in empirical studies of men and women in specific occupations, individual job-related characteristics explained only $42 \%$ to $67 \%$ of pay disparities); Oaxaca, Male-Female Wage Differentials in the Tclephone Industry, in Equal Employment Opportunity and the AT\&T Case 17, 34 (P. Wallace ed. 1976) ("substantial proportion" of wage differentials results from employer discrimination). 


\section{Comparable Work}

earnings differential, they do not explain pay disparities between individual men and women having similar qualifications and performing similar work.

Employers may treat men and women differently with respect to jobs and wages for various reasons. First, employers may act simply on the basis of prejudice. This prejudice may be the product of animus, ${ }^{22}$ or, if the employers hold strong beliefs about appropriate work-roles for women, of stereotyping.. ${ }^{23}$ Second, employers may discriminate in order to realize economic benefits. Sex-based discrimination may forestall labor disputes, when, for example, prejudiced male employees use formal ${ }^{24}$ or informal ${ }^{2 \tau}$ disruptive mechanisms to express their desire not to work with women. When governmental policies, such as state "protective" labor laws, require better conditions, more amenities, or extra benefits for women workers, employers may discriminate in order to reduce or recover the costs of compliance. ${ }^{26}$ Finally, profit motives may encourage employers to discriminate if they

22. See Boulding, supra note 19, at 10-12 (distrust and hatred contribute to personal prejudice); $c f$. G. Becker, The Economics of Discrimination 14 (2d ed. 1971) (discriminator is willing to pay in order to avoid association with some persons).

23. See Boulding, supra note 19, at $12-13$ (false generalizations and role stercotypes contribute to discrimination); Fiss, $A$ Theory of Fair Employment Laws, 38 U. CHI. L. REv. 235, 251 (1971) (stereotypes engender mistakes about productivity of individual workers, which encourage discrimination).

24. For example, unions dominated by male employces may enforce discriminatory policies through collective bargaining. See Shultz v. Wheaton Glass Co., 421 F.2d 259, 262 (3d Cir.), cert. denied, 398 U.S. 905 (1970) (union supported segregated job classifications and preferential hiring for men). Even if a union does not wish to discriminate, its obligation to bargain on behalf of all of its members may require it to support job and wage classifications that disadvantage women. See Laffey v. Northwest Airlines, Inc., 567 F.2d 499, 447 (D.C. Cir. 1976), cert. denied, 434 U.S. 1086 (1978) (union that assumed representation after establishment of discriminatory wage structure was unable to alter position of female workers at expense of male workers).

25. For example, male workers may refuse to work with women or may make the workplace inhospitable to women. See Kyriazi v. Western Elec. Co., 461 F. Supp. 894, 926 (D.N.J. 1978) (female engineer "subjected to odious personal harassment" by male co-workers); Barrett, supra note 3, at 48 (male workers sexually harass female co-workers, rearrange work environment, and refuse to cooperate with women).

26. These regulations directly and indirectly increase the cost of hiring women by requiring special expenditures. See Homemakers, Inc. v. Division of Indus. Welfare, 509 F.2d 20, 23 (9th Cir. 1974), cert. denied, 423 U.S. 1063 (1976) (state law required overtime premium for women). Employers may comply with protective laws by excluding women from some jobs, see, e.g., Corning Glass Works v. Brennan, 417 U.S. 188, 191 (1974) (state statute prohibiting women from working at night produced segregated day and night shifts); Palmer v. General Mills, Inc., 513 F.2d 1040, 1041 (6th Cir. 1975) (state-imposed hour and weight-lifting restrictions confined women to exclusively female division of one department), and may assess the costs of compliance against women's wages. SeE J. M.IDDEN, supra note 13, at 82 (laws effectively reduce women's marginal productivity and wages). The courts generally have concluded that compliance with state labor law's does not excuse violations of Title VII. See, e.g., Palmer v. General Mills, Inc., 513 F.2d at 1042; Kober v. Westinghouse Elec. Corp., 480 F.2d 240, 246 (3d Cir. 1973). 
perceive that women's bargaining position is weaker than men's. ${ }^{27}$

Employers respond to these joint pressures of bias and profit in at least two ways. First, employers may hire and assign workers of each sex selectively. Such sex-conscious placement practices magnify the disparate effect of a labor market in which women already suffer an initial disadvantage as a result of educational and employment patterns that may not be attributable to individual discriminators. ${ }^{28}$ This combination of employer practices and existing employment patterns has limited women's employment opportunities and produced horizontal and vertical job segregation. ${ }^{29}$ Men and women generally are found in different occupations or in different jobs within the same occupational category; ${ }^{30}$ the result of this division is to concentrate women workers in low prestige, dead-end jobs. ${ }^{31}$ In effect, men and women participate in separate labor markets. ${ }^{32}$

Second, employers may pay female workers lower relative wages. This practice both results from and contributes to other discriminatory employment practices. ${ }^{33}$ Because women's job choices are con-

27. See J. MADDEN, supra note 13, at 81-84 (monopoly power of male workers and market power of employers require women to accept employment on conditions offered by discriminators); $c f$. Corning Glass Works v. Brennan, 417 U.S. 188, 206 (1974) (Congress enacted Equal Pay Act in recognition of weak bargaining power of many women).

28. See pp. 659-60 supra.

29. Sex-based discrimination contributes to job segregation and limits employment opportunities in several ways that, although often illegal, persist. First, jobs may be reserved explicitly for members of one sex. See, e.g., Laffey v. Northwest Airlines, Inc., 567 F.2d 429, 437 (D.C. Cir. 1976), cert. denied, 434 U.S. 1086 (1978) (stewardess positions reserved for women while flight attendant and pursar positions reserved for men); Diaz v. Pan Am. World Airways, Inc., 442 F.2d 385, 387 (5th Cir.), cert. denied, 404 U.S. 950 (1971) (flight attendant positions reserved for women). Second, jobs may be implicitly sexlabeled by employment standards that exclude more women than men. See, e.g., Dothard v. Rawlinson, 433 U.S. 321, 328-31 (1977) (minimum height and weight standards established for prison guard positions); United States v. City of Milwaukee, 481 F. Supp. 1162, 1164-65 (E.D. Wis. 1979) (firefighter training required for paramedic appointments). Third, women may be restricted to certain jobs as a result of employers" assumptions about appropriate employment for women. At hearings before the EEOC in April 1980, the general counsel of the International Union of Electrical Workers and the Coalition of Labor Union Women testified that most workers "apply simply for a 'job,' and in almost all cases it is the employer alone who makes the decision as to which, if any, job the male or female or the black or white applicant should get." 104 LAB. ReL. Rep. (BNi) 5, 6 (1980) (News and Background Information).

30. See note 3 supra.

31. See Laws, Psychalogical Dimensions of Labor Force Participation of Women, in Equal Employment Opportunity and the AT\&T CAse 125, 131-32 (P. Wallace ed. 1976) (characteristics of women's jobs include low pay, lack of career continuity, and little specialization or on-the-job training); Taub, supra note 19, at 352 (same).

32. See J. KREPS, supra note 18, at 35-36 (separate labor markets result from sexlabeling of jobs); C. LloYd \& B. NiEMI, supra note 10, at 183-89 (men compete for highwage jobs while women are relegated to low-wage, relatively unskilled jobs).

33. In the absence of equal pay laws, pay discrimination and job segregation may be independent of one another; for example, unequal wages may be paid to men and women in the same job. 


\section{Comparable Work}

strained by discrimination, women are crowded into few occupations, ${ }^{3 *}$ are more likely than men to be unemployed or underemployed, ${ }^{35}$ and therefore are unable to command the same wage as similarly skilled men. ${ }^{36}$ To the extent that employers identify jobs as "women's work," wages for those jobs may be depressed, not only because women lack bargaining power, but also because the same work may be more highly valued when performed by men than by women. ${ }^{37}$ At the same time, the very existence of low-paying, female-identified jobs impedes the integration of the workplace because men can earn higher wages in more traditional fields. ${ }^{38}$

The most direct result of this interaction between discriminatory employment practices is that, when job classifications are segregated, employers are able to determine wages separately for men and women. ${ }^{39}$ Such wage-setting procedures enable employers to realize the benefits of discrimination without instituting an obviously inequitable wage structure or violating current interpretations of the law. It is clearly illegal for men and women to receive unequal wages for performing

34. "Occupational crowding" denotes an oversupply of workers available to meet employers" demand. See C. Lloyp \& B. Niem, supra note 10, at 213 (employer discrimination crowds women within occupations at bottom of promotion ladder); Barrett, supra note 3 , at 50-54 (number of female job-seekers exceeds number of opportunities in traditional female sector).

35. See U.S. Dep't of Labor \& Dep't of Health, Education, and Welfare, Employment And Trining Report of The President 265 (1979) (in 1978, unemployment rate for women aver 16 was $7.2 \%$; for men, $5.2 \%$ ); Keyserling, supra note 10 , at 30 (women's unemployment rate was, on arerage, $25 \%$ higher than men's rate between 1947 and 1975); cf. U.S. CoMm'N oN Civil RIGHTs, supra note 3 , at 28-30 (disparities between unemployment rates of white males and white and minority females very large and probably understated by traditional measures).

36. See Bergmann \& King, Diagnosing Discrimination, in Equal EMploymext OppoRTUNITY AND THE AT\&:T CASE 49, 49 ( $P$. Wallace ed. 1976) (women's wages less than wages of equally qualified white males because of artificially curtailed demand for female Iabor); Reagan, supra note 3 , at 90 (consequences of job segregation include undervaluing of work performed by women); cf. U.S. Comm'N oN Civil Rights, supra note 3, at $22-25$ (at every level of education, average male earnings exceed average female earnings).

37. See Laws, supra note 31 , at 129-30 (same job within Bell Telephone System paid higher wage in companies in which job was considered male than in companies in which job was considered female).

38. To achieve full integration of the workplace, both men and women must move into jobs traditionally reserved for or identified with the other sex. This fact is overlooked by some opponents of comparable work actions. See Nelson, Opton, \& Wilson, IVage Discrimination and the "Comparable Worth" Theory in Perspective, 13 U. MicH. J.L. REF. 23I, 295-96 (1980) (adoption of comparable worth theory would "imperil" job integration by reducing incentives for women to enter traditionally male fields).

39. See, e.g., International Union of Electrical, Radio \& Mach. Workers v. Westinghouse Elec. Corp., 631 F.2d 1094, $1096-97$ (3d Cir.), petition for cert. filed, 49 U.S.L.W. 3410 (U.S. Nov. 14, 1980) (No. 80-781) (employer allegedly set lower wages for all job classifications filled predominantly by women); Christensen v. Iowa, 563 F.2d 353, 351 (8th Cir. 1977) (exclusively female clerical jobs and predominantly male physical plant jobs of equal value paid unequal wages). 
the same work. ${ }^{40}$ Deliberately sex-conscious hiring and placement practices are also illegal under most circumstances. ${ }^{41}$ But because the use of sex as a factor to determine compensation is not now unlawful when men and women are in different jobs, employers are able to pay unequal wages for comparable work.

\section{B. The Failure of Title VII and Equal Pay Act Enforcement to Reduce Sex-Based Pay Disparities}

Two federal statutes prohibit sex-based discrimination in compensation."2 Title VII forbids an employer "to discriminate against any individual with respect to his compensation ... because of such individual's . . sex" or "to segregate or classify his employees in any way which would . . . adversely affect his status as an employee, because of such individual's . . . sex." 43 The Equal Pay Act requires employers to pay equal wages to men and women "for equal work on jobs the performance of which requires equal skill, effort, and responsibility, and which are performed under similar working conditions." 44

40. See p. 665 infra (current interpretations of Equal Pay Act and Title VII proscribe unequal wages when men and women perform "substantially equal" work).

41. Title VII provides that an employer may not "fail or refuse to hire . . . any individual . . because of such individual's ... sex" or "limit, segregate, or classify his employees or applicants for employment in any way which would deprive or tend to deprive any individual of employment opportunities . . . because of such individual's . . . sex." 42 U.S.C. $\$ 2000 \mathrm{e}-2$ (a) (1976). Title VII does not proscribe sex-conscious hiring when sex is a "bona fide occupational qualification." 42 U.S.C. $\$ 2000 \mathrm{e}-2$ (e) (1976); cf. Dothard v. Rawlinson, 433 U.S. 321, 334 (1977) (bona fide occupational qualification exception is "extremely narrow"). In addition, sex-conscious employment policies may be legal when adopted pursuant to a voluntary program of affirmative action. Cf. United Steelworkers v. Weber, 443 U.S. 193, 209 (1979) (Title VII permits employers to institute programs "designed to eliminate conspicuous racial imbalance in traditionally segregated job categories").

42. Equal Pay Act of 1963, 29 U.S.C. $\S 206$ (d) (1976); Civil Rights Act of 1964, $\S 703($ a), 42 U.S.C. $\$ 2000$ e-2(a) (1976) (Title VII). Pay discrimination on the basis of sex by federal contractors is also proscribed by Executive Order. Exec. Order No. 11,246, 3 C.F.R. 339 (1964-1965 Compilation), as amended by Exec. Order No. 11,375, 3 C.F.R. 320 (1967), reprinted in 42 U.S.C. $\$ 2000 \mathrm{e}$ (1976) ("contractor will not discriminate against any employee or applicant for employment because of ... sex"). The Office of Federal Contract Compliance Programs interprets the Executive Order to prohibit not only unequal pay for equal work, but other forms of sex-based pay discrimination as well. Accordingly, the agency has indicated that "compensation practices with respect to any jobs where males or females are concentrated will be scrutinized closely to assure that sex has played no role in the setting of levels of pay." 45 Fed. Reg. 86,250 (1980) (to be codified at 41 C.F.R. $\$$ 60-20.5(a)); see id. at 86,225 (regulation codifies existing policies and practices); 46 Fed. Reg. 9,084 (1981) (effective date of regulation deferred to April 29, 1981).

43. 42 U.S.C. $\$ 2000 \mathrm{e}-2$ (a) (1976). The proscription against the discriminatory classification of employees bans pay schedules that discriminate on the basis of sex. See International Union of Electrical, Radio \& Mach. Workers v. Westinghouse Elec. Corp., 631 F.2d 1094, 1097 (3d Cir.), petition for cert. filed, 49 U.S.L.W. 3410 (U.S. Nov. 14, 1980) (No. 80-781).

44. 29 U.S.C. $§ 206(d)(1)(1976)$. 


\section{Comparable Work}

Most courts have construed these statutes narrowly. The Equal Pay Act has been held to prohibit unequal pay only when men and women perform "substantially equal" 45 or "substantially identical" work.46 Although men's and women's jobs need not be identical in every respect, the focus of the court's inquiry under the Act is job content. ${ }^{47}$ Plaintiffs must show that any extra tasks assigned exclusively to men are not sufficiently important to justify the sex-linked difference in wages. ${ }^{48}$

Some suits challenging sex-based pay discrimination in jobs that are merely comparable, not equal, to men's jobs have been brought under Title VII. A number of courts have dismissed or rejected comparable work claims on the ground that Title VII does not prohibit any compensation practice that is not already prohibited by the Equal Pay Act. ${ }^{49}$ Under this interpretation, a plaintiff relying on Title VII also must prove that the defendant employer pays unequal wages for equal work.

The current judicial interpretation of Title VII and the Equal Pay Act leaves many women with no remedy for discriminatory compensation, because it precludes consideration of discriminatory pay practices that disadvantage workers in jobs filled exclusively or primarily by women. The work performed by women in segregated jobs frequently is not equal to the work performed by male employees; ${ }^{50}$

45. See, e.g., Gunther v. County of Washington, 602 F.2d 882, 887 (9th Cir. 1979), cert. granted, I01 S. Ct. 352 (1980) (No. 80-429); Shultz v. Wheaton Glass Co., 421 F.2d 259, 265 (3d Cir.), cert. denied, 398 U.S. 905 (1970).

46. See, e.g., Brennan v. City Stores, Inc., 479 F.2d 235, 238-39 (5th Cir. 1973); cf. Corning Glass Works v. Brennan, 417 U.S. 188, 203 n.24 (1974) ("[I]t is now well settled that jobs need not be identical in every respect before the Equal Pay Act is applicable....")

47. See Gunther v. County of Washington, 602 F.2d 882, 887 (9th Cir. 1979), cert. granted, 101 S. Ct. 352 (1980) (No. 80-429) (actual job performance and content determinative); Angelo v. Bacharach Instrument Co., 555 F.2d 1164, 1171 (3d Cir. 1977) (job content controlling for purpose of equating jobs).

48. See, e.g., Marshall v. Building Maintenance Corp., 587 F.2d 567, 569 (2d Cir. 1978) (additional tasks justify pay differential only when they consume significant amount of all male employees' time); Brennan v. Prince William Hosp. Corp., 503 F.2d 282, 286 (4th Cir. 1974), cert. denied, 420 U.S. 972 (1975) (citing cases in which extra tasks found to be "makeweights").

49. See, e.g., Lemons v. City \& County of Denver, 620 F.2d 228, 229-30 (10th Cir.), cert. denied, 101 S. Ct. 244 (1980) (Title VII comparable work claim barred because Equal Pay Act requires equal work); Di Salvo v. Chamber of Commerce, 568 F.2d 593, 596 (8th Cir. 1978) (Equal Pay Act standards apply in Title VII equal work case). But see, e.g., International Union of Electrical, Radio \& Mach. Workers v. Westinghouse Elcc. Corp., 631 F.2d 1094, 1097 (3d Cir.), petition for cert. filed, 49 U.S.L.W. 3410 (U.S. Nov. 14, 1980) (No. 80-781) (Title VII broader than Equal Pay Act); Gunther v. County of Washington, 602 F.2d 882, 891 (9th Cir. 1979), cert. granted, 101 S. Ct. 352 (1980) (No. 80-429) (same).

50. See note 6 supra (citing cases). 
the work performed by these women, however, may require the same objective qualifications, skill, effort, and responsibility as better paid jobs held by men. ${ }^{51}$ Moreover, because employers may have strong incentives to discriminate against women in setting wages, ${ }^{52}$ and because unequal pay for equal work is unlawful, women in segregated occupations are the most likely victims of inequitable wage payments. Yet the prohibition of intentional job segregation alone is insufficient to remedy this form of pay discrimination. Sex segregation is entrenched in the workplace, and the concentration of women in traditionally female occupations has increased since the enactment of Title VII. ${ }^{53}$ Occupational integration is a long-term goal, providing no relief to present victims of discrimination. ${ }^{54}$ The current need is for an effective cause of action grounded in equal pay for comparable work.

\section{Eliminating Sex-Based Discrimination Using Title VII}

Although the courts' refusal to require equal pay for comparable work under the Equal Pay Act is probably justified, ${ }^{55}$ the same nar-

51. Based on job evaluations, see pp. 674-76 infra, jobs filled by women frequently are found to be comparable to better paid jobs held by men. See, e.g., Christensen v. Iowa, $563 \mathrm{F.2d} \mathrm{353,} 354$ (8th $\mathrm{Cir}$. 1977) (clerical and physical plant jobs placed in same labor grade after employer's job evaluation); D. Treiman, Job Evaluation: AN ANalytic Review 27-28 (1979) (Washington State job study found wages for women's jobs averaged $80 \%$ of wages for men's jobs with same evaluation scores).

52. See p. 661 supra (identifying prejudice and economics as motives for sex-bascd discrimination).

53. See Barrett, supra note 3 , at 50-51 (percentage of all women workers employed in clerical and service jobs increased from 1965 to 1977); Reagan, supra note 3, at 95 (percentage of women employed in 10 predominantly female occupations increased between 1960 and 1975).

54. Cf. Reubens \& Reubens, Women IVorkers, Nontraditional Occupations and Full Employment, in WOMEN IN THE U.S. LABOR ForCE 103, 121-22 (A. Cahn ed. 1979) (desegregating workplace will not ensure that sex-based earnings differentials will be eliminated).

55. This judicial construction is consistent with the language of the Act, which proscribes unequal wages for "equal work." 29 U.S.C. $\$ 206(d)$ (1976). Moreover, the legislative history of the Act reveals that Congress explicitly rejected a comparable work formula in favor of the equal work standard. In 1962 the word "equal" was substituted for the word "comparable" in H.R. 11677, 87th Cong., 2d Sess. (1962), by a floor amendment. 108 Cong. REc. 14771 (1962). Both the Senate and House bills reported out of committee the following year mandated equal pay for "equal work on jobs the performance of which requires equal skill, effort and responsibility and which are performed under similar working conditions." S. 1409, 88th Cong., Ist Sess., 109 CoNG. REC. 8866 (1963); H.R. 6060, 88th Cong., lst Sess., 109 Cong. Rec. 9210 (1963). During the House debate, Representative Goodell explained that use of the word "equal" rather than "comparable" meant that "the jobs involved should be virtually identical, that is, they would be very much alike or closely related to each other." 109 CoNG. Rec. 9197 (1963); see Senatr Comm. on Labor and Public Welfare, Equal Pay Act of 1963, S. Rep. No. 176, 88th Cong., 1st Sess. 2 (1963) (" $\mathrm{N}] \mathrm{o}$ employee can be paid a wage rate less than that given to another doing the same work, because of his or her sex"). 
row interpretation of Title VII is not consistent with the broad remedial purpose of the latter statute. Title VII can and should be used to attack pay discrimination when men and women who perform comparable work do not receive equal wages.

\section{A. The Scope of Title VII}

The courts have offered two justifications for finding that Title VII requires equal pay only when men and women perform equal work. First, the Bennett Amendment ${ }^{56}$ to Title VII has been construed to mean that, in sex-based discrimination cases, Title VII does not bar any wage practice not already prohibited by the Equal Pay Act.57 Second, some courts have suggested that Title VII's general prohibition of discriminatory compensation practices does not reach the payment of unequal wages for comparable work. ${ }^{58}$ These conclusions, however, are inconsistent with the objectives of Title VII.

\section{The Bennett Amendment}

The Bennett Amendment to Title VII provides that "differentiation upon the basis of sex" in determining compensation is not unlawful "if such differentiation is authorized by [the Equal Pay Act]." "59 The courts have offered two interpretations of the Amendment according to their understanding of the term "authorized." Two Circuit Courts of Appeals have held that the Equal Pay Act "authorizes" unequal wage payments only in the sense that the Act creates several specific defenses to equal pay claims. ${ }^{60}$ These defenses include proof that wages are based on seniority and merit systems, systems that measure earnings "by quantity or quality of production," and "any other differential based on any other factor other than sex." 11 According to this view, the Bennett Amendment does not restrict the scope of

56. 42 U.S.C. $\$ 2000 \mathrm{e}-2(\mathrm{~h})$ (1976).

57. See, e.g., Lemons v. City \& County of Denver, 620 F.2d 228, 229-30 (10th Cir.), cert. denicd, 101 S. Ct. 244 (1980); International Union of Electrical, Radio \& Mach. Workers v. Westinghouse Elec. Corp., 17 Fair Empl. Prac. Cas. 16, 22 (N.D. W. Va. 1977).

58. See, e.g., Lemons v. City \& County of Denver, 620 F.2d 228, 230 (10th Cir.), cert. denied, $101 \mathrm{~S}$. Ct. 244 (1980) (no denial of equal opportunity when pay and job classification system provided for equal pay for equal work); Christensen v. Iowa, 563 F.2d 353 , 356 (8th Cir. 1977) (equal opportunity "not at issue" when employees receive disparate wages for different jobs that may be equally valuable).

59. 42 U.S.C. $\$ 2000 \mathrm{e}-2(\mathrm{~h})(1976)$.

60. See International Union of Electrical, Radio \& Mach. Workers v. Westinghouse Elec. Corp., 631 F.2d 1094, 1106-07 (3d Cir.), petition for cert. filed, 49 U.S.L.W. 3410 (U.S. Nov. 14, 1980) (No. 80.781); Gunther v. County of Washington, 602 F.2d 882, 891 (9th Cir. 1979), cert. granted, 101 S. Ct. 352 (1980) (No. 80-429).

61. 29 U.S.C. $\$ 206(\mathrm{~d})(1)$ (1976); see note 118 infra (explaining Equal Pay Act defenses). 
equal pay suits under Title VII, but merely guarantees that a defendant in such a suit may raise the same defenses that would be available if the action had been brought under the Equal Pay Act.

Other courts have interpreted the pay differentiation "authorized by" the Equal Pay Act to refer to all inequalities in pay not expressly prohibited by that Act. ${ }^{62}$ Relying on this construction, many courts have held that, as a result of the Bennett Amendment, Title VII does not prohibit unequal pay for comparable work because such disparities are not prohibited by the Equal Pay Act. ${ }^{63}$

The former interpretation better conforms to the goals of Title VII. ${ }^{64}$ The Bennett Amendment's legislative history, although ambiguous, more clearly supports the view that the Amendment's purpose was to permit the Equal Pay Act defenses to be raised in equal pay actions under Title VII. ${ }^{65}$ In addition, in the absence of an ex-

Under the Equal Pay Act, the burden is on the employer to show that a wage disparity is within the enumerated exceptions. Corning Glass Works v. Brennan, 417 U.S. 188, 196-97 (1974).

62. See, e.g., Lemons v. City \& County of Denver, 620 F.2d 228, 229.30 (10th Cir.), cert. denied, 101 S. Ct. 244 (1980); Molthan v. Temple Univ., 442 F. Supp. 448, 454 (E.D. Pa. 1977).

63. See note 57 supra (citing cases).

64. Title VII clearly prohibits all types of pay discrimination based on race, color, national origin, or religion, including, but not limited to, unequal pay for equal work. See, e.g., International Union of Electrical, Radio \& Mach. Workers v. Westinghouse Elec. Corp., 631 F.2d 1094, 1096-97 (3d Cir.), petition for cert. filed, 49 U.S.L.W. 3410 (U.S. Nov. 14, 1980) (No. 80-781) (classification of jobs in which different wages paid because of race, religion, or national origin would violate statute); Quarles v. Philip Morris, Inc., 279 F. Supp. 505, 509-10 (E.D. Va. 1968) (unequal pay for comparable work because of race violates statute). If the Bennett Amendment were interpreted to mean that the statute prohibits only compensation practices prohibited by the Equal Pay Act, a sharp distinction between sex and other group characteristics would have to be read into Title VII. Courts have resisted this result. See, e.g., International Union of Electrical, Radio \& Mach. Workers v. Westinghouse Elec. Corp., 631 F.2d at 1100 (expressing reluctance to "conclude that Title VII would allow discriminatory behavior on the basis of sex, when the same behavior would be prohibited if made on the basis of race, religion or national origin"); Patterson v. Western Dev. Labs, 13 Fair Empl. Prac. Cas. 772, 776 (N.D. Cal. 1976) (illogical to employ one standard to decide claims of sex-based pay discrimination and another standard for pay discrimination based on race).

65. The Amendment was introduced in the Senate as a floor amendment to Title VII. Comments made by two Senators during the debate support the interpretation proposed in this Note. The Amendment's sponsor, Senator Bennett, stated that its purpose was to ensure that "in the event of conflicts, the provisions of the Equal Pay Act shall not be nullified." 110 Cong. Rec. 13,647 (1964). His statement apparently means that the Amendment was intended to prevent the application of inconsistent decisional standards in Title VII equal work cases and Equal Pay Act cases. This interpretation of Senator Bennett's comment is supported by Senator Dirksen's remark that the Amendment only recognized the exceptions "carried in the [Fair Labor Standards Act]." 110 Cong. Rec. 13,647 (1964).

A third legislator, however, disagreed with this construction. Representative Celler stated: "The Senate amendment ... [p]rovides that compliance with the Fair Labor Standards Act as amended satisfies the requirements of the title barring discrimination 
plicit statement of congressional intent, the courts generally have construed Title VII's provisions in ways that benefit the members of protected groups and that narrow the exceptions to the Act's prohibition of discrimination. ${ }^{66}$ Finally, the Equal Employment Opportunity Commission's Guidelines adopt this less restrictive interpretation. ${ }^{67}$ Ac-

because of sex." 110 Cong. REc. 15,896 (1964). This explanation implies that Title VII only prohibits unequal pay for equal work.

These remarks in the Senate and the House constitute the whole of the discussion of the Amendment's effect at the time of its adoption. Given the comments of Senators Bennett and Dirksen, and considering that Senator Bennett was the bill's sponsor, the legislative history on balance provides more support for the reading of the Amendment advocated in this Note than for a more expansive reading.

66. Thus, although Title VII prohibits discrimination against whites as well as blacks "because of" race, the Supreme Court has decided that it does not forbid employers to institute voluntary race-conscious affirmative action programs that disadvantage some white workers. United Steelworkers v. Weber, 443 U.S. 193, 209 (1979). Despite statutory language precluding challenges to disparate treatment based on a "bona fide seniority or merit system" or on the results of a "professionally developed ability test," 42 U.S.C. $\$ 2000$ e-2(h) (1976), the Court has ordered retroactive seniority for victims of employer discrimination, see Franks v. Bowman Transp. Co., 424 U.S. 747, 761-62 (1976), and invalidated ability tests that exclude more blacks than whites, see Albemarle Paper Co. v. Moody, 422 U.S. 405, 436 (1975). In addition, the Court has construed narrowly the statutory exceptions to Title VII's prohibitions. See Dothard v. Rawlinson, 433 U.S. 321, 334 (1977) (bona fide occupational qualification is "extremely narrow exception" to general proscription of sex-based discrimination).

67. EEOC Guidelines issued in $\mathbf{1 9 7 2}$ provide that "by virtue of [the Bennett Amendment], a defense based on the Equal Pay Act may be raised in a proceeding under Title VII." 29 C.F.R. $\$ 1604.8$ (b) (1979). This Guideline is entitled to judicial deference because the Commission has adhered to one interpretation of the Bennett Amendment. Compare Dothard v. Rawlinson, 433 U.S. 321, 334 n.19 (1977) (EEOC construction of statute entitled to weight when agency has adhered to consistent position) with General Elec. Co. v. Gilbert, 429 U.S. 125, 142-44 (1976) (EEOC Guideline that "flatly contradicts" earlier position entitled to little consideration). An earlier version of the current Guideline, adopted in 1965, provided:

Title VII requires that its provisions be harmonized with the Equal Pay Act ...

in order to avoid conflicting interpretations or requirements with respect to situa.

tions to which both statutes are applicable. Accordingly, the Commission interprets

[the Bennett Amendment] to mean that the standards of "equal pay for equal work"

set forth in the Equal Pay Act for determining what is unlawful discrimination in compensation are applicable to Title VII.

30 Fed. Reg. 14,928 (1965). Most of the courts that have examined the 1965 Guideline have interpreted it to mean that Equal Pay Act liability standards apply in equal pay for equal work cases brought under Title VII. This reading does not impair the availability of an action for equal pay for comparable work under Title VII. See, e.g., International Union of Electrical, Radio \& Mach. Workers v. Westinghouse Elec. Corp., 631 F.2d 1094, 1105-06 (3d Cir.), petition for cert. filed, 49 U.S.L.W. 3410 (U.S. Nov. 14, 1980) (No. 80-781) (noting that under 1965 Guideline, EEOC made administrative determinations of pay discrimination when men and women did not perform equal work); Gunther v. County of Washington, 602 F.2d 882, 891 (9th Cir. 1979), cert. granted, 101 S. Ct. 352 (1980) (No. 80-429) (1965 Guideline not inconsistent with conclusion that Bennett Amendment only makes Equal Pay Act defenses available in Title VII actions). But see International Union of Electrical, Radio \&: Mach. Workers v. Westinghouse Elec. Corp., 17 Fair Empl. Prac. Cas. 16, 22 (N.D. W. Va. 1977) (1965 and 1972 Guidelines entitled to no consideration because inconsistent). 
cordingly, the Bennett Amendment should be read narrowly in order to permit equal pay for comparable work claims under Title VII.

\section{Title VII Policy}

Assuming that the Bennett Amendment should be narrowly construed, Title VII's broad proscription of discriminatory compensation practices plainly encompasses other types of pay discrimination in addition to unequal pay for equal work. When Congress enacted Title VII to guarantee equal opportunities to members of protected groups, ${ }^{\text {bs }}$ it recognized that disparities in earnings between blacks and whites were an important aspect of employment discrimination in need of redress. ${ }^{69}$ Accordingly, the Act was designed to reach "a wide range of incidents" and "all aspects of discrimination in employment." When Congress amended Title VII in 1972 to enlarge the enforcement powers of the Equal Employment Opportunity Commission, it found that sex-based disparities in earnings represented "a profound economic discrimination against women workers," and indicated that the lower compensation of women because of their sex was "particularly objectionable" because such practices had been prohibited since 1964..$^{71}$

The courts also have emphasized the expansive character of Title VII's prohibitions. The Supreme Court has stated that the Act prohibits "all practices in whatever form" that present obstacles to fair treatment of individual employees. ${ }^{72}$ This proscription includes practices that are fair in form but discriminatory in effect, ${ }^{73}$ as well as

68. Sex discrimination was included among the practices proscribed by Title VII by a floor amendment passed one day prior to House passage of the Civil Rights Act. See 110 Conc. REc. 2577, 2584 (1964). As a result, there is little evidence of Congress' intent with respect to the scope of the prohibition. See General Elec. Co. v. Gilbert, 429 U.S. 125, 143 (1976) (legislative history "notable primarily for its brevity"). However, when Congress amended Title VII in 1972, see Equal Employment Opportunity Act of 1972, Pub. L. No. 92-261, 86 Stat. 103 (amending 42 U.S.C. $\$ \$ 2000 \mathrm{e}-2$ to $2000 \mathrm{e}-17$ (1976)), it explicitly recognized that "[d]iscrimination against women is no less serious than other forms of prohibited employment practices." H. REP. No. 238, 92d Cong., 2d Sess. 5, reprinted in [1972] U.S. Code Cong. \& AD. \& NEws 2137, 2141.

69. S. REP. No. 867, 88th Cong., 2d. Sess. 9 (1964) ("key facts" include lower expected lifetime earnings of blacks than whites and concentration of blacks in unskilled and semi-skilled jobs at low wages).

70. Id. at 10 .

71. H.R. ReP. No. 238, 92d Cong., 2d Sess. 4, reprinted in [1972] U.S. Code CoNG. \& AD. NEws 2137, 2140.

72. Franks v. Bowman Transp. Co., 424 U.S. 747, 763 (1976); see Taub, supra note 19, at 403.05 (evolving Title VII standard currently focuses on neutral merit-based evaluation of individuals).

73. Practices that have a disparate impact on members of a protected class can survive a Title VII challenge only if they are shown to be justified by "business necessity," that is, that they are closely related to measuring job capability or performance, or are 
intentional acts of discrimination. ${ }^{74}$ In light of its broad remedial objectives, the statute has been held to protect workers against racebased pay discrimination that does not involve a denial of equal pay for equal work. ${ }^{75}$ If the Bennett Amendment is interpreted narrowly, Title VII's prohibition of sex-based discrimination in compensation is equally comprehensive. ${ }^{76}$

Several courts have asserted, however, that Title VII does not prohibit unequal pay for comparable work because it does not authorize any interference with the labor market or with "the laws of supply and demand." 77 This argument, that the Act's proscriptions do not reach employment decisions or practices that are based on market factors or economic considerations, reflects a misconception about Title VII.

First, Title VII's primary objective is the achievement of equitable, not efficient, employment practices. Interference with the marketintervention in decisionmaking and invalidation of discriminatory

essential to the safety and efficiency of business operations. See, e.g., Nashville Gas Co. v. Satty, 434 U.S. 136, $143 \&$ n.5 (1977) (denial of accumulated seniority to employees returning from maternity leave not justified by business necessity); Dothard v. Rawlinson, 433 U.S. 321, 328-32 (1977) (minimum height and weight standards that disqualified more women than men not related to job requirement of strength); Blake v. City of Los $\Lambda$ ngeles, 595 F.2d 1367, $1376-77$ (9th Cir. 1979), cert. denied, 100 S. Ct. 1865 (1980) (sexsegregated job classifications maintained by police department not justified by administrative consenience or financial considerations). Some courts have stated that the employer also must prove that no less harmful alternative practice is available. See, e.g., Robinson v. Lorillard Corp., 444 F.2d 791, 798 (4th Cir.), cert. dismissed, 404 U.S. 1006 (1971) (business necessity means no acceptable alternative practice "would better accomplish the business purpose advanced, or accomplish it equally well with a lesser differcntial [sex-based] impact"); $c f$. Blake v. City of Los Angeles, 595 F.2d at 1376-77 (business necessity doctrine is "very narrow").

74. See, e.g., International Bhd. of Teamsters v. United States, 431 U.S. 324, 335-37 (1977) (blacks and Hispanics "regularly and purposefully" treated less favorably than whites); Fitzgerald v. Sirloin Stockade, Inc., 624 F.2d 945, 950 (10th Cir. 1980) (employer consistently denied plaintiff salary commensurate with responsibilities).

75. See note 64 supra.

76. The courts have held that Congress intended to proscribe all sex-based discrimination. See City of Los Angeles, Dep't of Water \&: Power v. Manhart, 435 U.S. 702, 707 n.13 (1978) ("Congress intended to strike at the entire spectrum of disparate treatment of men and women resulting from sex stereotypes.") Courts have applied the exacting standards developed in race cases, see, e.g., Griggs v. Duke Power Co., 401 U.S. 424, $431-32$ (1971) (invalidating diploma and test requirements that disproportionately excluded black job applicants), to cases of alleged sex-based discrimination. See, e.g., Nashville Gas Co. v. Satty, 434 U.S. 136, 141-43 (1977) (using Griggs standard to invalidate maternity leave policy that adversely affected women); Dothard v. Rawlinson, 433 U.S. 321, 329 (1977) (using Griggs standard to invalidate height and weight requirements that disproportionately excluded women).

77. Christensen v. Iowa, 563 F.2d 353, 356 (8th Cir. 1977) (Congress did not intend "to abrogate the laws of supply and demand or other economic principles that determine wage rates for various kinds of work"); accord, Lemons v. City \& County of Denver, 620 F.2d 228, 229 (10th Cir.), cert. denied, 101 S. Ct. 244 (1980). 
choices made by individual employers-is exactly what the Act requires. It establishes a general rule that the race, color, national origin, sex, and religion of employees and job applicants may not be considered in employment decisions. ${ }^{78}$ This proscription cannot be avoided merely because doing so may appear to be efficient under some circumstances. ${ }^{79}$ For example, Title VII does not permit an employer to pay men and women unequal wages for equal work even if the prevailing wage rate for qualified female workers is lower than for qualified males ${ }^{80}$ Similarly, employment decisions may not be predicated on accurate generalizations about groups described by race or sex, even though the use of such proxies may reduce the employer's costs. $^{81}$

Second, even if Title VII does concern efficiency, ${ }^{82}$ it embodies an assumption that inequitable employment practices impair the operation of the labor market, in that such practices are ultimately inefficient. ${ }^{83}$ In this view, a market that favors or promotes discriminatory decisions based on group characteristics like race and sex is defective because these traits are not related to the capabilities of individual workers. Interference with the market is therefore warranted, and con-

78. 42 U.S.C. $\S 2000 \mathrm{e}-2$ (a) (1976).

79. Discrimination may be efficient from the employer's point of view if sex or race is a good predictor of productivity or if the employer incurs extra costs by hiring women. See C. Lloxd \& B. NiEMI, supra note 10, at 187 (search costs for information about productivity encourage "statistical discrimination" based on use of readily observed traits such as sex as proxies); p. 661 supra (discussing effects of employee prejudice and state labor laws). The assertion that higher costs are associated with employing women, however, is not a good defense to a charge of discrimination under either the Equal Pay Act or Title VII. See, e.g., City of Los Angeles, Dep't of Water \& Power v. Manhart, 435 U.S. 702, 717 (1978) (although average cost to employer of providing pension benefits to women was higher than average cost of providing benefits to men, employer may not require women employees to make larger contributions to pension fund); EEOC v. Colby College, 589 F.2d 1139, 1144-45 (Ist Cir. 1978) (employer may not provide lower annuity benefits to female employees than to male employees despite higher cost).

Discrimination is also efficient from the employer's perspective if the employer faces customers who are discriminators. See Diaz v. Pan Am. World Airways, Inc., 442 F.2d 385, 389 (5th Cir.), cert. denied, 404 U.S. 950 (1971) (customers' preference for female flight attendants did not justify discrimination).

80. The willingness of women to work for a lower wage than men is not "any other factor other than sex," 29 U.S.C. $\$ 206(d)$ (1976), which would justify unequal wages under the Equal Pay Act. See, e.g., Corning Glass Works v. Brennan, 417 U.S. 188, 205 (1974); Brennan v. Victoria Bank \& Trust Co., 493 F.2d 896, 902 (5th Cir. 1974).

81. See City of Los Angeles, Dep't of Water \& Power v. Manhart, 435 U.S. 702, 708 (1978) ("Even a true generalization about the class is an insufficient reason for disqualifying an individual to whom the generalization does not apply.")

82. Cf. Fiss, supra note 23 , at 313 (antidiscrimination legislation reflects not only intention to benefit disadvantaged groups, but also commitment to "economic efficiency and individual fairness").

83. See S. REP. No. 867, 88th Cong., 2d Sess. 2 (1964) (underutilization of black labor force estimated to have economic cost in billions of dollars). 
sistent with the promotion of economic interests, ${ }^{84}$ when discrimination occurs.

\section{B. Limitations on an Expanded Title VII Standard}

The comparable work standard proposed in this Note would not provide a remedy to all victims of pay discrimination. For example, if no predominantly male job in the plaintiff's place of employment is comparable to her job, or if an employer's workforce is entirely female, the plaintiff would be unable to prove that she is paid less than men performing comparable work. ${ }^{85}$ This limitation is imposed by Title VII, which requires equitable treatment of employees within, but not between, firms. ${ }^{\text {so }}$

Nor does Title VII mandate equal wages if different wages can be explained by nondiscriminatory, business-related factors. ${ }^{87}$ To avoid liability under a comparable work standard, the defendant should be permitted to show that unequal wages are explained by factors not related to sex. This showing might be subsumed in a business necessity defense to an action based on a disparate impact theory. ${ }^{88} \mathrm{Al}$ ternatively, because of the Bennett Amendment this showing might be based on the Equal Pay Act defenses. ${ }^{83}$

The most problematic aspect of requiring equal pay for comparable work is the identification of comparable jobs. ${ }^{90}$ This task requires an

84. See McDonnell Douglas Corp. v. Green, 411 U.S. 792, 801 (1973) (Title VII reflects societal interest in "efficient and trustworthy workmanship assured through fair and racially neutral employment and personnel decisions"); Developments in the Law-Employment Discrimination and Title VII of the Civil Rights Act of 1964, 84 HARv. L. Rev. 1109 , 1118 (1971) (Title VII may be viewed as attempt to accelerate perfection of the market).

85. Women workers in such jobs might nevertheless obtain relief if they can demonstrate that their employer would pay a higher wage to men doing comparable work. Cf. Roesel v. Joliet Wrought Washer Co., 596 F.2d I83, 186 (7th Cir. 1979) (sex-based discrimination found when court could infer that male employee performing equal work to female plaintiff would have received higher salary).

86. Sce 42 U.S.C. $\$ 2000 c-2(a)$ (1976) (statute prohibits an "employer" from discriminating against individual employees); Brest, The Supreme Court, 1975 Term-Foreword: In Defense of the Antidiscrimination Principle, 90 HARv. L. REv. 1, 6-8 (1976) (law forbids "race-dependent" decisions by individual employers).

87. See note 119 infra (discussing business necessity defense).

88. See id.

89. See note 118 infra (discussing Bennett Amendment defenses to comparable work actions).

90. Professor Blumrosen asserts that an employer's liability for pay discrimination could be established without the identification of comparable jobs. She argues that a prima facie case in comparable work actions should require no more than proof that:

jobs have been segregated in the past or present, that jobs are identified as female or minority jobs, that a wage rate structure exists for the segregated jobs which is low in the employer's overall structure, or that a job is traditionally reserved for minorities or women throughout the labor force.

Blumrosen, Wage Discrimination, Job Segregation, and Tille VII of the Civil Rights Act 
assessment of job content. In particular, the nature and the difficulty of job duties must be analyzed because these factors determine relative wages. ${ }^{11}$ At the same time, the courts must compare jobs according to a procedure that is independent of the market price for labor in jobs filled by women. Job evaluation techniques offer one method for comparing jobs that are dissimilar in content but that may nevertheless be comparable. ${ }^{92}$

\section{Job Evaluation and the Comparable Work Standard for Achieving Equitable Pay}

Employers routinely use job evaluation systems to translate information about the content of different jobs into appropriate wage rates. In comparable work actions, courts could use these systems to scrutinize challenged rates of pay by taking account of factors that legitimately influence compensation. The Title VII prima facie case could readily be adapted to include proof of comparable work through the use of job evaluation procedures. The potentially discriminatory features of such procedures should not preclude their use as a tool for attacking discriminatory wage structures.

\section{A. Job Evaluation}

Job evaluations are one method that employers use to establish pay schedules. Job evaluation systems are designed to order a set of jobs or positions so that dissimilar work can be compared to determine appropriate relative wage levels. ${ }^{93}$ Their methodology assumes that

of 1964, 12 U. MICH. J.L. REF. 397, 468 (1979). This formulation starts from the premise that, absent proof to the contrary, the market rate for segregated jobs reflects discrimination. Id. at 488. Even if this premise is correct, Blumrosen's test is flawed because it does not require the plaintiff to show that her job is comparable to some better paid male job or that her wages are in fact discriminatory. Her test adopts a societal perspective and does not conform to the Title VII prima facie case established by decisional law. See pp. 677-78 infra (plaintiff has burden of proving facts sufficient to raise inference of discrimination).

91. See A. Rees, The Economics of Work and Pax 166-69 (1973).

92. Alternatively, comparable jobs could be identified through marginal productivity analysis. See Nelson, Opton, \& Wilson, supra note 38, at 257 ("[M]arginal productivity analysis measures the worth of work by the value that ... [it] adds to the total output of the enterprise.") Employers rarely determine actual wages by marginal products, howcver, because their measurement is difficult. $I d$. at $257 \&$ n.113. Job evaluation procedures therefore represent a more practical method for identifying comparable work justifying equal pay.

93. See D. Bezcher, Compensation Administration 88 (1974); D. Treiman, supra note 51, at I (interim report to EEOC on job evaluation methodology by National Research Council of National Academy of Sciences). Job evaluation systems are used to achieve equitable wage relationships between jobs within a single organization. Mossholder, Nurick, 
remuneration should be based on the content of the job rather than on the characteristics of its holder, ${ }^{94}$ and that the compensable elements of job content can be identified and measured. ${ }^{95}$ Most public and private entities with more than a small number of employees rely on job evaluations or on a related procedure to construct systems of compensation..$^{90}$

Job evaluations are completed by developing occupational descriptions according to which each job being studied may be ranked or scored. That hierarchy is then converted into a compensation schedule. In firms with few employees, the use of subjective ranking or classification systems may be feasible. ${ }^{97}$ The majority of plans, however, depend on the identification of generalizable, compensable factors, ${ }^{98}$ the assignment of point values or weights to each factor for each job, ${ }^{99}$

Gordon, \& Pryor, An EPA Exceptions Model-Cracking the Sex-Based Wage Differential, Compensation Rev., First Quarter 1979, at 42; Thomsen, Eliminating Pay Discrimination Caused by Job Evaluation, PERSonnel, Sept.-Oct. 1978, at 11-12.

A job-content based method for setting wages and salaries scrves various objectives. First, the pay structure will be comprehensible and appear rational to employees. Second, an ordered wage structure facilitates setting rates for new or altered jobs and provides a basis for discretionary rewards based on seniority, merit, or individual production. Third, use of a system may strengthen the position of the employer relative to employee organizations, reducing grievances and facilitating wage negotiations. See D. BELCHER, supra, at 91-92; H. Stanway, Applied Job Evaluition 8 (1947); cf. EEOC v. Kenosha Unified School Dist. No. 1, 620 F.2d 1220, 1225 (7th Cir. 1980) (union requested job evaluations that supported pay differential).

94. See D. BelCher, supra note 93, at 88; D. Treiman, supra note 51, at 1 .

95. The compensable elements of a job include discrete tasks or duties and less tangible factors such as effort. See $\mathbf{R}$. Sibson, supra note 5 , at $29-30$ (job analysis requires information about difficulty of jobs, amount of time they require, nature of job objectives, weight of demands on jobholders, and quality of work environment); D. Treiman, supra note 51, at I (same). In some cases, the compensable factors chosen will be few in number, see id. at 3 (four to seven factors), but in others, jobs will be mcasured by many discrete characteristics. Sec D. BeLcher, supra note 93 , at $140-41$ (over 50 factors). The identification and measurement of appropriate factors is most successful when the jobs being studied are similar. Therefore, job evaluation plans for job clusters-jobs linked by production function, skill, or some other characteristic, see Livernash, The Internal IVage Structure, in Compens.jion and Reward Perspectives 157, 160-61 (T. Mahoney ed. 1979)-are used more often than plans for whole organizations. D. Treiman, supra note 51 , at 5 .

96. See D. Treiman, supra note 5I, at $49 \mathrm{n}$.I (federal government, most state and large county governments, and, according to available evidence, majority of large private firms use formal job evaluation procedures).

97. Ranking systems entail an evaluation of "whole jobs," rather than job components, to develop a hierarchy of job values. See D. BELCHER, supra note 93, at 146-49; D. Treman, supra note 5l, at 2. Classification systems, by contrast, involve the development of an ideal hierarchy of jobs according to overall difficulty or valuc. Existing and new jobs are then assigned values by comparing their characteristics with this classification system. See D. Belcher, supra note 93, at I49-50; D. Treman, supra note 51, at 2-3.

98. See note 95 supra.

99. For cxample, a skill factor could be measured on a five-step scale in which the first step requires "average learning ability and good aptitude for factory operations"; the third, "some specific knowledge such as blueprint reading"; and the fifth, "extensive 
and the comparison of total values for all jobs. ${ }^{100}$ The compensable factors that are frequently used in job evaluations are reflected in the language of the Equal Pay Act; ${ }^{101}$ they include the amounts of skill, responsibility, and physical and mental effort requisite to job performance, and the quality of the work environment. ${ }^{102}$ The total values quantify the worth of each job to the employer.

Job values are converted into wage rates by constructing a curve that specifies an ideal relationship between scores and wages. ${ }^{103} \mathrm{Job}$ evaluation data may be translated directly into compensation levels or utilized in combination with information on prevailing market rates or union demands. ${ }^{104}$ Area wage rate surveys are often employed to anchor the wage curve to the relevant labor market. ${ }^{105}$

Job evaluation techniques have been assailed by some advocates of pay equity because these techniques, like the employment and placement tests that are a continuing focus of Title VII litigation, ${ }^{106}$ can be used to justify unfair compensation practices. ${ }^{107}$ Yet such techniques

technical knowledge gained through formal training." Each step on the scale would correspond to a different point award for skill. R. Sibson, supra note 5, at 41; cf. D. BeLcher, supra note 93, at 176-78 (showing representative scales for other compensable factors).

100. Factors may be weighted for comparison in terms of dollars rather than points. According to this method, certain jobs are selected as benchmark jobs, and their wage rates are accepted as appropriate. The evaluator then decides what proportion or amount of the total wage for each benchmark job is attributable to each factor. Each factor for every other job is assigned a value in comparison to the benchmark job. The appropriate wage for each job is arrived at by summing the dollar values assigned to each job factor. See D. Belcher, supra note 93, at 157-69; D. Treman, supra note 51, at 3-4.

101. See Corning Glass Works v. Brennan, 417 U.S. 188, 201 (1974) (Congress deliberately incorporated job evaluation terminology into Equal Pay Act).

102. 29 U.S.C. $\$ 206$ (d) (1976); cf. D. Tr.em.n, supra note 51, at 6-7 (skill, effort, responsibility, and work environment are universal factors).

103. See D. Treiman, supra note $5 \mathrm{I}$, at 4, $50 \mathrm{n} .2$ (scores may be converted into wages using straight-line wage curve or methods as sophisticated as linear regression analysis).

104. See D. Belcher, supra note 93, at 254-5j (current wage rates, union demands, market rates, and cost consequences of jobs may be considered); D. Treiman, supra note 51 , at 2 (area wage rates, company policy decisions, union demands, and traditional ratcs among possible considerations).

105. See D. BELCHER, supra note 93, at 458-59; R. SiBson, supra note 5, at 56-59.

106. See, e.g., Albemarle Paper Co. v. Moody, 422 U.S. 405, 425.36 (1975) (ability tests used for job placement); Griggs v. Duke Power Co., 401 U.S. 424, 431-36 (1971) (personncl tests and high school diploma requirement for job placement).

107. See, e.g., Blumrosen, supra note 90 , at 434-43 (discussing discriminatory àpects of wage-setting procedures); Kronstadt, Job Valualion-Bias for Hire, 1979 NAT1ON 777, 778. 79 (criticizing subjectivity of evaluation process). A rccent National Academy of Sciences report on the utility of job evaluation systems in resolving claims of pay discrimination concluded that the systems have three important limitations:

1. the choice of factors and factor weights can have strong effects on the relative ranking of jobs;

2. evaluations ultimately rest on subjective judgments (although systems differ in the degree of subjectivity involved); and

3. the use of different job evaluation plans for different segments of an olganiza. 


\section{Comparable Work}

may also be used to attack pay discrimination and should not be dismissed simply because they may be susceptible to abuse. The job evaluation study is the best available method of identifying jobs that are comparable though not equal.

\section{B. Implementation of the Comparable Work Standard}

The proposed equal pay-comparable work standard would be applied according to the general standards developed in Title VII decisional law. To establish a prima facie case, the plaintiff would need to show that her job is comparable ${ }^{108}$ to a job held predominantly by men $^{109}$ and that there is a disparity between the wage rate for her job and for the comparable male job. She must demonstrate that the pay disparity adversely affects women employees as a group, ${ }^{110}$ or that women are deliberately paid lower wages than men.111 Comparable work claims will frequently be raised in conjunction with

tion's work force precludes comparisons of the relationship of pay to job worth across sectors.

D. Trenman, supra note 51 , at 30 .

Proponents of equal pay for comparable work who reject job evaluation methodology have not proposed an alternative method for comparing dissimilar jobs. See Blumrosen, supra note 90, at 493-95 (proposing use of "reformed" job evaluation procedures to remedy pay discrimination); Comment, Equal Pay for Comparable Work, 15 HARv. C.R.-C.L. L. REv. 475, 495 (1980) (suggesting no method for identifying jobs requiring "similar degrees of training, experience and responsibility").

108. Plaintiffs must establish that male and female jobs are comparable in order to raise an inference of discrimination. But see Comment, supra note 107, at 494 (proposing that statistics showing disparate impact of compensation practices should be sufficient to establish prima facie Title VII violation). To demonstrate that the work of men in the comparison job is comparable to her own, the plaintiff should be required to show that the job evaluation scores of men's and women's jobs are approximately the same. Several considerations favor proof of equality by a range of scores. First, job evaluation systems are not so precise that defendants should be allowed to avoid liability because job scores differ by one or two points. Second, in practice, employers generally assign the same wage to broad classes or grades of jobs. See D. BelCHER, supra note 93, at 25759; R. Sibson, supra note 5, at 45-46. Plaintiffs should not be held to a more exacting standard. Ideally, the EEOC would establish standards for job comparability demanding equal pay.

109. A job may be considered a "sex-segregated" women's job for the purposes of Title VII litigation even if a significant minority of the jobholders are male. See, e.g., D. Treiman, supra note 51, at 27 (Washington State comparable worth study defined sexsegregated jobs as jobs in which at least $70 \%$ of incumbents were of same sex); Blumrosen, supra note 90, at 461 (Women's Bureau of Federal Department of Labor uses $70 \%$ figure).

110. This showing would be accomplished with statistics demonstrating a disparity between the average earnings of men and women in comparable jobs. A disparity of any size would support the plaintiff's case. The plaintiff could employ regression analysis to demonstrate that the pay disparity is not related to nondiscriminatory factors. See Fisher, Multiple Regression in Legal Proceedings, 80 Colum. L. Rev. 702, 721-25 (1980) (discussing use of regression analysis in wage discrimination litigation).

111. See note 74 supra (discussing disparate treatment theory). 
allegations that the employer has violated other provisions of Title VII. ${ }^{112}$ Evidence that her employer's hiring or placement practices are illegal might also support the plaintiff's argument that the payment of unequal wages for comparable work is explained by discrimination..$^{113}$

The job comparison leading to a finding of pay discrimination in segregated occupations could be accomplished during pretrial proceedings in one of several ways. The Equal Employment Opportunity Commission, or a similar state or local agency, ${ }^{114}$ could conduct a job study in the course of its complaint investigation. ${ }^{115}$ Private plaintiffs could employ experts to evaluate the work of men and women and to prepare job evaluations for presentation to the court. ${ }^{116}$ Data from an employer's own job evaluations should also support a comparable work claim if jobs with equal scores pay unequal wages. ${ }^{117}$

Once the plaintiff has established her prima facie case, the employer would be required to offer a nondiscriminatory explanation for the unequal rates of compensation in order to avoid liability. The Bennett Amendment allows an employer to rebut the prima facie case by showing that wage differentials are based on a seniority, merit, or incentive system, or on some other factor not related to sex. ${ }^{118}$

112. See, e.g., Greenspan v. Automobile Club, 22 Fair Empl. Prac. Cas. 184, 186 (E.D. Mich. 1980) (combined challenge to hiring, promotion, compensation, and other practices); Kohne v. Imco Container Co., 480 F. Supp. 1015, 1016 (W.D. Va. 1979) (combined challenge to compensation, assignment, disciplinary practices, and other conditions of employment).

113. Evidence concerning hiring and placement practices would be relevant in a comparable work action because job segregation and pay discrimination are interrelated. See pp. 662-64 supra.

114. See note 9 supra (discussing when charges must be filed with state or local agency).

115. See 42 U.S.C. $\$ 2000 \mathrm{e}-5$ (b) (1976) (EEOC authorized to investigate charges to determine whether reasonable cause exists to pursue legal action); cf. Marshall v. J.C. Penney Co., 464 F. Supp. 1166, 1190-91 (N.D. Ohio 1979) (job evaluation evidence presented by Secretary of Labor in Equal Pay Act case); EEOC v. Sheet Metal Workers Local 122, 463 F. Supp. 388, 402-03 (D. Md. 1978) (EEOC used expert witness to analyze job qualifications).

116. See, e.g., Kohne v. Imco Container Co., 480 F. Supp. 1015, 1030, 1038-39 (W.D. Va. 1979); Wetzel v. Liberty Mut. Ins. Co., 449 F. Supp. 397, 402-05 (W.D. Pa. 1978).

117. See Plaintiffs' Memorandum in Opposition to Motion for Partial Summary Judgment re: Compensation Claims at 79-80, National Organization for Women v. Minnesota Mining \& Mfg. Co., Civ. No. 4-74-555 (D. Minn., filed Aug. 4, 1980) (exhibit C) (employer allegedly used separate wage curve to establish lower pay for women's jobs than for men's jobs with equal job evaluation scores). But see Christensen v. Iowa, 563 F.2d 353 , 354 (8th Cir. 1977) (showing that employer paid unequal wages for clerical and physical plant jobs with same job evaluation scores did not establish Title VII prima facie case).

118. See pp. 667-69 supra (Bennett Amendment permits Equal Pay Act defenses to bc raised in Title VII actions). The excepted merit, seniority, and incentive systems need not be in written form, but must be standardized so that the same criteria are applied to all employees. In addition, the basic elements of the system must have been communi- 
Under Title VII, wage-setting procedures that have a disparate impact on men and women in comparable jobs could be justified by a showing of business necessity. ${ }^{119}$ If the plaintiff proceeds on a disparate treatment theory, the defendant must prove a nondiscriminatory explanation for the different wages. ${ }^{120}$ The willingness of women to accept a lower wage than men, however, would not be a defense. ${ }^{121}$ In deciding comparable work claims, courts would be required to weigh expert testimony and assess job evaluation and other statistical evidence. ${ }^{122}$ Complexity is characteristic of much Title VII litigation,

cated to the employees. E.g., EEOC v. Aetna Ins. Co., 616 F.2d 719, 725 (4th Cir. 1980); Brennan v. Victoria Bank \& Trust Co., 493 F.2d 896, 901 (5th Cir. 1974).

The courts have given considerable attention to the phrase "any other factor than sex." Some employers have argued that participation in training programs is a factor that should justify wage disparities. Training programs are evaluated like merit, seniority, and incentive systems: the program must be formal in some sense and employees must be aware of its existence. E.g., Marshall v. Security Bank \& Trust Co., 572 F.2d 276, 279 (10th Cir. 1978); Shultz v. First Victoria Nat'l Bank, 420 F.2d 648, 655-57 (5th Gir. 1969). Training programs that do not include women "carry a stigma of suspect validity" under the Equal Pay Act, Hodgson v. Behrens Drug Co., 475 F.2d 1041, 1048 (5th Cir.), cert. denicd, 414 U.S. 822 (1973), and may be illegal under Title VII, see 42 U.S.C. $\$ 2000$ e2(d) (1976) (prohibiting discrimination in training and apprenticeship programs).

The Third Circuit has held that the different average profitability of work performed by men and women may also justify pay disparities. See Hodgson v. Robert Hall Clothes, Inc., 473 F.2d 589, 597 (3d Cir.), cert. denied, 414 U.S. 866 (1973) (higher gross profits of men's clothing department, in which all salespersons were male, than of women's clothing department, in which all salespersons were female, justified higher wages for men). A defense based on economic benefits to the employer, however, should be allowed only when those benefits are related to individual job performance. See, e.g., Pearce v. Wichita County, 590 F.2d 128, 134 (5th Cir. 1979) (higher collection rate of male credit manager might explain raises during employment but could not justify different base salaries of male and female credit managers); Comment, 122 U. PA. L. Rev. 1039, 1042 (1974) (use of gross profits test in Robert Hall incorrect because profit differential may be related to sex-based discrimination by employer or industry).

119. See note 73 supra (test of business necessity requires proof that practice having disparate impact is job-related or essential to safe and efficient operation of business). In comparable work actions, a business necessity defense might involve validation that the criteria used by the employer to establish wage levels are job-related and not sex-biased. See Thomsen, supra note 93, at 16 (validation eliminates bias in job evaluation factor choice and factor weights).

120. See, e.g., Board of Trustees v. Sweeney, 439 U.S. 24, 24 (1978) (defendant must "articulate" nondiscriminatory explanation); Furnco Constr. Corp. v. Waters, 438 U.S. $567,577-78$ (1978) (same). The plaintiff may attempt to show in rebuttal that the defendant's explanation of its action is a pretext for discrimination. McDonnell Douglas Corp. v. Green, 411 U.S. 792, 804 (1973).

121. See note 80 supra.

122. The complexity of job evaluation procedures requires that courts carefully scrutinize job evaluations prepared for use in litigation. Courts should require precise definitions of the compensable factors employed and give greater weight to evaluations prepared by multiple cvaluators. See D. Treman, supra note 51, at 43 (participation of several persons improves reliability); $c f$. $\mathbf{R}$. Sibson, supra note 5, at 50 (evaluator's judgments must be screened for personal bias or prejudice). The factors chosen should be validated to overcome discriminatory effects. See Thomsen, supra note 93 , at 16. EEOC Guidelines for conducting job evaluations would assist the courts in assessing job evaluation results. 
and the courts should not be deterred from hearing comparable work claims by concerns about manageability. In exceptionally difficult cases, the supervision of job studies by a special master may be appropriate. ${ }^{123}$ Finally, the wage rate established by the employer for the comparable male job should be used as the standard for adjusting depressed wages paid to women. ${ }^{124}$

\section{Conclusion}

Many women relegated to low-paying jobs are unable to obtain relief from discriminatory wages because the courts have given a narrow reading to Title VII's prohibition of discrimination in compensation. That interpretation is not justified in view of the Act's broad remedial purposes. Title VII can and should be used to attack wage differentials even when men and women are not performing substantially equal work.

The proposed comparable work standard is only a partial solution to the problem of pay discrimination and occupational segregation. Discriminatory earnings differentials can be fully eliminated only through full occupational integration. At present, however, integration is a distant goal. The equal pay for comparable work standard would provide relief for present victims of discriminatory pay practices.

123. The Federal Rules of Civil Procedure permit the appointment of a special master in cases that are especially burdensome or require unique expertise. FED. $R$. Civ. P. 53(b); see Note, "Mastering" Intervention in Prisons, 88 YALE L.J. 1062, 1068 (1979). Masters have been appointed frequently in Title VII cases to assist in the determination of relief. See, e.g., Thompson v. Boyle, 23 Empl. Prac. Dec. 15,906, 15,914 (D.D.C. 1980); Kohne v. Imco Container Co., 480 F. Supp. 1015, 1039 (W.D. Va. 1979). In other cases, masters have supervised discovery and assisted the court in making factual determinations. See, e.g., Zegers v. Zegers, Inc., 458 F.2d 726, 727 (7th Cir. 1972); First-Iowa Hydro Elec. Coop. v. Iowa-Illinois Gas \& Elec. Co., 245 F.2d 613, 618 (8th Cir.), cert. denied, 355 U.S. 871 (1957).

124. See, e.g., Hodgson v. Miller Brewing Co., 457 F.2d 221, 226-27 (7th Cir. 1972) (employer may not reduce wage rate of any employee to comply with Equal Pay Act); Quarles v. Philip Morris, Inc., 279 F. Supp. 505, 509-10 (E.D. Va. 1968) (wage rate for black jobs raised to rate for comparable white jobs). 